\title{
Lactation Massage for Increasing Breast Milk Production in Postpartum Mothers
}

\author{
Katmini $^{1}$, Nazilatul Maulinda Sholichah ${ }^{2}$ \\ ${ }^{1}$ Master Program of Public Health Institute of \\ Health Sciences Strada Indonesia \\ ${ }^{2}$ Faculty of Public Health Sciences IIK Strada \\ Indonesia \\ Email: \\ katminitini@gmail.com
}

Received: October 5, 2020

Accepted : October 14, 2020

Published : November 30, 2020

\begin{abstract}
Breast milk is the best food for babies. But breastmilk production which is little or not smooth in the first days of delivery becomes an obstacle in breastfeeding. The study conducted by Collin and a scot in Australia showed that 556 mothers gave birth as many as $29 \%$ had stopped breastfeeding their babies in the second week on the grounds that their milk was lacking. The lack of milk production causes many mothers to easily provide prelacteal foods. This prelacteal feeding causes the amount of exclusive breastfeeding to decrease. To obtain a scientific reference source about lactation massage, which in previous studies can increase milk production in postpartum mothers. This study is a metadata analysis using a literature review that explores the benefits of massage to increase milk production. Literature sources used are journals from Pubmed, Garuda, DOAJ, Researchgate and Google Scholar. With the principle of working to maximize the mechanism of prolactin and oxytocin receptors, lactation massage is a solution to overcome the smooth production of breast milk and minimize the side effects of delayed breastfeeding. In a study conducted by Aprilianti, lactation massage had a tendency to rapid onset of lactation 5.57 times greater than mothers who received oxytocin massage. This article tries to examine the problem of breastfeeding in postpartum mothers based on literature review. In general the role of lactation massage is successful in smoothing milk production, but there are a number of things that need to be evaluated.
\end{abstract}

Keyword: Breast milk production, massage, postpartum

Copyright (C) 2020 IIK STRADA Indonesia All right reserved.

This is an open-acces article distributed under the terms of the Creative Commons Attribution-ShareAlike 4.0 International License.

\section{INTRODUCTION}

Breast milk is the best food needed in the first 6 months of a baby's life. Early breastfeeding is an optimal form of infant nutrition. Meanwhile, the mother through the process of breastfeeding can help involution, reduce weight gain after giving birth and reduce the risk of breast cancer. Complaints about lack of milk production are a problem with the incidence rate between 11-54\%. 
The lack of milk production has caused many mothers to easily provide prelacteal foods such as milk, honey, coconut water, bananas and starch water. This prelacteal feeding causes a reduction in the number of exclusive breastfeeding, allergies, until the death of the baby due to the digestive system is not ready to process pre-treat food (Department of Health R.I. 2015).

Infant Mortality Rate (IMR) is an indicator of health status in the third Sustainable Development Goal (SDGs), namely Good Health and Well-being. The infant mortality rate in Indonesia in 2016 was $23.5 / 1000 \mathrm{KH}$ from the target SDGs of $12 / 1000 \mathrm{KH}$ in 2015-2030. From the description above, Indonesia ranks highest compared to Vietnam (17.8/1000), Malaysia (12.9/1000), and Thailand (9.4/1000). Risk factors for infant mortality events can be influenced by the quality of ANC services, the nutritional status of pregnant women, indicators of the MCH and family planning program, and the environmental situation and economic status (Ministry of Health RI, 2017)

In the process of lactogenesis, when the placenta comes out, the hormone progesterone and estrogen which is initially high becomes decreased. But there is still residual blood circulation so that the activity of minimal emphasis on prolactin is still present. As soon as the baby suckles signals will be sent to the hypothalamus gland in the brain (anterior pituitary) to produce the hormone prolactin, prolactin will circulate in the blood and enter the breast, causing the development of alveoli cells until the distance between alveoli cells becomes tight and milk production increases. Here this is needed by the hormone oxytocin which can express milk through reflex letdown. The causes of oxytocin work are hampered, such as postpartum stress, postpartum fatigue, not getting full support from the closest people, and fear because breastfeeding is not enough (Riordan J. \& Wambach K., 2015).

To increase milk production, various methods that can be performed on postpartum mothers due to the decrease in the hormone oxytocin include nonpharmacological therapies such as the use of herbs, acupuncture, imagery, massage and the use of cabbage leaves. Massage therapy can be done simply as needed by postpartum mothers namely oxytocin massage, back massage, oketani relaxation massage and lactation massage because it has benefits to increase milk production (Machmudah, 2017).

The purpose of this study is to obtain a scientific reference source about lactation massage, which in previous studies can increase milk production in postpartum mothers. It is hoped that this can be applied effectively to health services and become a recommendation for midwifery intervention in providing care to postpartum mothers with breastfeeding problems not yet out or not smooth.

\section{MATERIALS AND METHODS}

Guide question: Does lactation massage affect the increase in milk production in postpartum mothers? Keywords in Indonesian: massage, milk production, and postpartum mothers. Inclusion criteria: articles in Indonesian/ fulltext English, and articles published in 2015-2019 with keyword massage, milk production, and postpartum mothers. Exclusion criteria: articles that are more than 5 years old, do not have a complete structure, review articles, articles that did not occur in massage, milk production, and postpartum mothers as well as articles that did not answer research statements. This research method uses descriptive analysis with this type of study is metadata that uses a literature review (Literature review) that explores the benefits of lactation massage to increase milk production in postpartum mothers compared with other methods and massages. The strategy in this research is to use 20 articles from a database in the form of journals that discuss in Indonesian and English, it is from pubmed, Garuda (digital reference guard), researchgate, DOAJ and Google Scholar from 2015 to 2019. The keywords used are massage, milk production, and postpartum mothers.

\section{RESULTS}

The search process through the database found 36.768 articles from pubmed, 2.590.400 articles from google scholar, 15.464 articles from Garuda (digital reference garba), 9.448 articles 
from DOAJ and 94,095 articles from researchgate, the number of articles identified was 650.430 , selected> last 5 years and 262.626 articles were identified. Of the 262.626 articles identified, 262.095 articles were found to be irrelevant to the study. Then a selection was made to find 531 proper full text articles. The final stage of selection found several articles that did not answer the research statement, namely 511 articles. The final results were 20 articles that were included, all corresponding to quantitative studies and published between 2015 and 2019. 18 studies were conducted in Indonesia, 1 study in America and 1 study in India. Each of these 20 articles has been read carefully starting from the abstract, objectives, data analysis from the researcher's initial questions, and conclusions to gather information about the research.

The first article is a study conducted by Jahriani in Sendang Sari Village, Asahan Regency with the title Effect of Lactation Massage on Breast Milk Production in Mothers. The research design uses Quasi Experiment. The statistical test in this study is the Chi Square test. The results of the study stated that lactation massage has an effect on increasing milk production by increasing the volume of milk and the frequency of breastfeeding infants by increasing the hormone prolactin (Jahriani N. 2019).

The second article is about massage on postpartum with onset lactation. The sampling technique is purposive sampling. The sample in this study was 40 postpartum mothers in the Independent Practice of Midwives in Palangka Raya City. The research design used is a quasi experiment with Non-Equivalent Control Group Design. The results of this study showed that postpartum mothers who performed lactation massage had an average lactation onset of 35.05 hours while postpartum mothers who performed oxytocin massage on lactation were slower ie on average 49.14 hours (Dewi R.A. \& Cia A, 2018).

The third research article is about benefits of nape massage and muscle massage pectoralis major to breast milk storage in postpartum day 1 and day 2 conducted at KRT Setjonegoro Regional Hospital The type of research used was a comparative observational analytic method with cross sectional approach. Samples are taken by sampling or incidental samples. Bivariate analysis uses related t-sample tests. The results of this study are that there are benefits of nape massage and pectoralis major muscle massage on breast milk removal in postpartum day 1 and day 2 with the price of tcount $>t$ table $(11,500>2,045)$ (Suryani. 2015).

The fourth study was conducted in Palangka Raya, with the title lactation massage and oxytocin massage against onset lactation. The research design used quasi experiment. The sampling technique was purposive sampling. The analysis used was Chi Square. Of the 15 mothers who received lactation massage $75 \%$ experienced a rapid onset of lactation. Of the 7 mothers who received oxytocin massage, only $35 \%$ had a rapid onset of lactation. From the OR it was concluded that mothers who received lactation massage had a tendency to have rapid onset of lactation 5.57 times greater than mothers who received oxytocin massage $(p$-value $=0.026)($ Aprilianti, 2018).

The fifth article is a study conducted by Poncokusumo Subdistrict, Malang Regency with the title of back massage and acceleration of breast milk production in postpartum mothers. Popupasi in this study were 64 postpartum mothers. The sampling technique with non probability sampling is accidental sampling with a total of 20 samples that meet the inclusion criteria, each 10 samples for the control and intervention groups. Statistical test using the uni Man Whitney U-Test. The results showed that there was an effect of back massage on breast milk expenditure. This is evidenced by the value of $p<0.05$ which is 0.029 . The effect is postpartum mothers who get back massage treatment express breast milk faster than those who do not get a massage (Safitri et al. 2015).

The sixth research article is a study conducted in Rowokele Health Center, Kebumen Regency with the title of combination of back massage and endorphins to breast milk production in pospartum. This type of research used Quasi Experiment, using post test only design with control group design. Postpartum mothers in the Rowokele region were the target population in this study. The number of samples is 22 samples for each group (intervention and control) sampling technique with consecutive sampling. Bivariate analysis using ci square with a significant level of $p<0.005$. The results of this study are the back massage group and the control group there are differences in the smooth production of breast milk. The chances of smooth milk production of 0.2 for mothers 
who received back massage and endorphin massage intervention compared to the control group (Dewi, et al. 2017)

The seventh study was conducted in Kediri, with the title of breast milk production with acupresure point for lactation and oxytocin massage. The study design used a quasi experiment with a pre post test design with control group design. The sample consisted of 27 primiparous postpartum mothers, who were divided into 3 groups with the acupresure point for lactation intervention, oxytocin massage intervention, and the control group. The results showed the results of comfort analysis $\mathrm{p}=0.035$. Mothers who received acupresure point for lactation felt more comfort and more milk production than mothers who received oxytocin massage interventions, and mothers who received oxytocin massage interventions had more milk than the control group (Rahayu, D. et al. 2015).

The eighth article was carried out in the inpatient department of Obstetrics and Postgraduate pediatrics at a tertiary nurse teaching hospital in central India. The title of this study is the Effect of back Massage on Lactation among Postnatal Mothers. This research method uses Quasi Experiment, with the number of samples of the intervention group of 10 samples and the control group of 10 samples. Obtained results, a significant increase in baby's weight, the number of bowel movements and urination more, the duration of the baby's sleep longer after breastfeeding (Patel \& Gedam. 2016)

The ninth study is a study with the title is efektivitas pijat oksitosin dan aromatherapy clary sage terhadap onset laktasi. This research is a quantitative research with a quasi-experimental design through the non equivalent control group approach. Popupasi as many as 38 postpartum mothers who have not released colostrum within 2 hours after delivery. Test statistics using mannwhitney. The results showed the average lactation onset in the oxytocin massage group and clary sage aromatherapy was 4.21 hours while in the oxytocin massage group was 6.37 hours (Septiani. et al. 2018)

The tenth study was conducted at the Waikabubak District Hospital with the title of effectiveness of lactation massage, oxytocin massage and combination of breast milk production in mothers with caesaria section. This research method uses Quasi experiment with pre post test design. The sample size was 33 mothers with caesarean section. The results of this study are that there are differences in the average increase in milk production. The average for oxytocin massage is 2762.91 , for back massage is 3057.64 and the combination of oxytocin massage and back massage is 3456.18 . This means that there is an increase in milk production with a combination of oxytocin massage and back massage in mothers with caesarean section (Florida. et al. 2018).

The eleventh article is a study conducted by Albertina in Samarinda. The title of this research is Oxytocin Massage Relationship with Smooth Breast Milk Production in Postpartum Mother Sectio Caesarea on days 2-3. The study design uses cross sectional. The number of samples in this study were 48 respondents. The sampling technique uses total sampling. The statistical test in this study is the chi square test. The results of the study revealed a significant relationship between oxytocin massage with smooth milk production (X2 count - 8.765> X2 table 3,841, $P$ value $=0,003)$ (Albertina et al. 2015).

The twelfth article is a study conducted by Dewi Ariani in Malang Raya with the title of The Effect of Relaxation Suplementer combined with oxytocin massage and lavender aromatherapy on Baby Weight Loss. The measured variable is the increase in baby's weight. The study design uses Quasi Experiment with Group Design pre-test only control. The study population was mothers who had breastfeeded and had problems in breastfeeding. These problems include lack of breast milk, giving breast milk combined with formula milk and never stop breastfeeding. The sample was divided into 4 groups, namely supplementation relactation, supplementation relactation and oxytocin massage, supplementation relactation and lavender aromatherapy, and supplementary relactation with aromatherapy combination of lavender therapy with oxytocin massage. The results of this study are the supplementation of the supplementation of aroma combination lavender therapy with oxytocin massage does not significantly affect the baby's weight gain. (Ariani et al. 2017)

The thirteenth study was a study entitled effect of oxytocin massage on increased breast milk production in breastfeeding mothers at Plus Mandiangin Community Health Center. The 
research design uses Quari Experiment with pre test and post test design approaches. The number of samples in the study were 21 samples. The results of this study were the average milk production before oxytocin massage at 7.05 and standard deviation of 0.740 and the average milk production after oxytocin massage at 9.00 and standard deviation of 1.183 . While the difference in ASI production between pre and post measurements is an average of -1.952 with a standard deviation of 1.161. Statistical test results obtained a p-value of 0.000 , it can be concluded that there is an influence of oxytocin massage on milk production, because there is a significant difference between milk production before and after treatment (Delima et al. 2016).

The fourteenth study was a study carried out in Tanjung Pinang under the title of oxytocin massage and breast care to smooth breast milk production in nifasi mothers. The research method uses preexperiment with one group pretest-posttest design. The number of samples in this study were 36 samples, with consecutive sampling technique. Data analysis using the Wilcoxon Test. The results showed that oxytocin massage was more effective in increasing milk production compared to breast care. (Seribu and Wasis. 2015)

The fifteenth article is metode SPEOS (Stimulation of Endorphin, Oksitosin Massage, and Sugestive) can increase breast milk production and increase baby weight. This study uses the Wilcoxon test. Quasi experimental research design with one group pre-post test design. The results show that the SPEOS method has an effect on increasing milk production and increasing infant weight. (Nugraheni \& Heryati, 2016)

The sixteenth article is a research conducted in Breastfeeding Medicine of Northeast Ohio (BFMEDNEO) entitled Therapeutic Breast Massage in Lactation for the Management of Engorgement, Plugged Ducts, and Mastitis. The result of this study is that therapeutic breast massage in lactation (TBML) can significantly reduce pain in cases of swelling, attached ducts, and mastitis (Bolman. 2015).

The seventeenth article is The Effect of Combined Marble and Axytocin Massage to Colostrum Production Among the Caesarean Mother Section. The results showed that the average amount of colostrum produced by mothers who received a combination of Marmet and oxytocin massage techniques (the treatment group) was $5.333 \mathrm{cc}$ with a standard deviation of 4.6368 . On the other hand, the mean of those who did not receive the combined massage technique (control group) was $0.0289 \mathrm{cc}$ with a standard deviation of 0.03551 . The statistical test results obtained $\mathrm{p}$ value $=$ 0.009. As $\mathrm{p}$ value $<\alpha(0.05)$ (Barirah, et al.2017).

The eighteenth article is Effect of Combination of Oxytocin Massage and Hypno breast feeding on uterine involution and Prolactin Levels in Postpartum Mothers. The conclusion in this study is that there is a statistically significant effect of the combination of oxytocin massage and hypnobreast administration at the level of uterine involution and prolactin in puerperal mothers at Semarang General Hospital (Aini et al. 2017).

The nineteenth article is The Effect of Lactapuncture Massage on Breast Milk Production through Prolactin Hormone Levels Changes in Dr. M. Ashariospital, Pemalang, Central Java. This study used univariate analysis with normality, homogeneity, and bivariate analysis. The results of this study were that after being given lactapuncture massage intervention for 7 consecutive days, the prolactin hormone level in the intervention group was higher than the control group but it was not statistically significant (Patimah et al. 2019).

The twentieth article is Effectiveness of the combination of marmet technique and oxytocin massage against the breast milk production of postpartum mother. This study used a quasiexperimental method with post test only with control group design with purposive sampling. The results of the bivariate test using independent $t$-test obtained $p$ value $(0.007)<\alpha(0.05)$ which means that there is a significant influence between breast milk production in the intervention group and postpartum breast milk production in the control group and the average milk production (Darmasari et al. 2019).

\section{DISCUSSION}

From 20 journals selected there were 4 journals using lactation massage and 16 journals relevant to the author's research title. From the 20 journals above, it can be concluded that massage 
therapy can effectively increase milk production. Massage therapy can be done simply according to the needs of postpartum mothers. Massage therapy is an easy and safe intervention to do in postpartum mothers. This intervention can also be carried out by the patient's husband or family after being trained by a midwife / health worker.

Lactation massage is a massage performed on several parts of the body, namely the head, neck, shoulders, back, and breasts (Dewi \& Aprilianti. 2018). Lactation massage performed on nursing mothers will stimulate the muscles of blood vessels in the breast to stimulate the hormone prolactin in producing milk. Besides lactation massage will make breasts cleaner, softer and elastic so that it will provide comfort for the baby to breastfeed (Jahriani, N. 2019). In certain circumstances lactation massage can be done to stimulate milk production, for example helping the process of induction of breastfeeding for adoption / mother lift / never breastfeed (Hapitria, 2017).

This statement is not much different from the research journal with oxytocin massage. Oxytocin massage is spinal massage in the back region (Dewi \& Aprilianti. 2018). Oxytocin massage is carried out from the costae (ribs) to 5-6 extending both sides of the spine to the scapula (shoulder blade). Oxytocin massage through neurotransmitters will stimulate modulla oblongata by sending the hypothalamus message in the posterior pituitary, it stimulates the let down reflex to secrete the hormone oxytocin into the blood. Oxytocin that enters the circulatory system stimulates the contraction of myioepithelial cells surrounding the mammary alveoli and lactiferous ducts. Myoepithelial cells that contract to stimulate the alveoli secrete milk through the lactiferous duct into the lactiferous sinus. When a baby sucks, the milk that comes out in the sinuses experiences pressure that causes milk to come out into the baby's mouth (Hajerah, 2015).

In research conducted by Dewi (2018) mentioned that mothers who performed lactation massage intervention had a faster onset of lactation with an average value of 35.05 hours compared to oxytocin massage which was 49.14 hours. In principle, these two massages cause a relaxing effect to increase the hormone oxytocin. The difference in lactation onset in this case can be caused by lactation massage carried out more massage points on the body than oxytocin massage, namely the head, neck, shoulders, back, and breast, as well as a longer massage duration of \pm 30 minutes. Whereas for oxytocin massage only massage in the back area for \pm 15 minutes. With massage at some point, especially in the breast area, lactation massage can increase milk production compared to oxytocin massage. This is relevant to research conducted by Hapitria (2017) which states that breast tissue contains lots of lymph vessels and blood vessels, vessels that are blocked become the cause of lack of smooth production and flow of breast milk. In this case, according to the title of the study conducted by the author that lactation massage is a more effective massage technique in increasing milk production.

In a study conducted Safitri et al. (2015) mentioned shoulder blades are areas of muscle tension in women, so massage is done in these areas to relax or relieve stress. When the spine is massaged, neurogenic reflexes that accelerate the work of the parasympathetic nerve to convey commands to the back of the brain. As a result of stimulatory signals, the response of oxytocin is released into the systemic blood from the posterior pituitary. Oxytocin blood flow is delivered to myioepithelial cells around the alveoli, oxytocin stimulates these cells so that the alveolar sac is depressed, pressure rises, the duct shortens and widens. Then when the nipples are sucked, the milk comes out faster than the control group.

$Z_{\text {score }}>1,96$ or $Z_{\text {score }}>-1,96$ and also obtained a significant value $=0.029<\alpha=0.05$ then $\mathrm{H} 0$ is rejected $\mathrm{H} 1$ is accepted. In conclusion, there is a significant effect between back massage on the acceleration of breast milk expenditure, which is the acceleration of milk output on the 2-3 day.

Table 2. Accelerated breast milk expenditure on respondents who received treatment and respondents who did not get back massage treatment

\begin{tabular}{lcccc}
\hline \multicolumn{1}{c}{$\begin{array}{c}\text { Acceleration of breast milk } \\
\text { expendure }\end{array}$} & \multicolumn{4}{c}{ Back Massage } \\
& $\mathrm{F}$ & $\%$ & $\mathrm{~F}$ & $\%$ \\
\hline Fast (day 1) & 0 & 0 & 0 & 0 \\
Normal (day 2-3) & 10 & 100 & 6 & 60 \\
For a long time (day 4) & 0 & 0 & 4 & 40 \\
Total & 10 & 100 & 10 & 100 \\
\hline
\end{tabular}


Table 3. The onset of lactation in Postpartum mothers based on the type of massage.

\begin{tabular}{cllll}
\hline Tipe of & & \multicolumn{3}{c}{ Onset of lactation (hour) } \\
Massage & F & Mean & SD & p-value \\
\hline Lactation & 20 & 35,05 & 12,327 & 0,002 \\
Oxytocin & 20 & 49,14 & 15,055 & \\
\hline
\end{tabular}

From the above data it can be concluded that the acceleration of breast milk expenditure in mothers with lactation massage intervention is faster which is 35.05 hours compared to mothers with back massage intervention which is 2-3 days. This is in line with the title of the study conducted by the author, that lactation massage can accelerate the smooth production of breast milk (Dewi, \& Aprilianti. 2018).

Besides the back massage method, there is another method, endorphin massage. So far, endorphin has been known as a substance that has many benefits. Some of them are regulating the production of growth and sex hormones, controlling pain and persistent pain, controlling feelings of stress, and enhancing the immune system (Dewi. 2017). An obstetrician, Constance Palinsky moves to use Endorphin massage to normalize heart rate, blood pressure, and improve the relaxed condition in the body of pregnant women by triggering a sense of comfort through the surface of the skin. (Irawati. 2018)

Table 4. Relationship of Back and Endorphin Combination to breast milk Production in Postpartum Mothers (Dewi et al. 2017)

\begin{tabular}{|c|c|c|c|c|c|}
\hline \multirow{3}{*}{$\begin{array}{l}\text { Independent } \\
\text { variable }\end{array}$} & \multicolumn{4}{|c|}{ Breast Milk Production } & \multirow{3}{*}{ OR } \\
\hline & \multicolumn{2}{|c|}{ Smoothly } & \multicolumn{2}{|c|}{ Not Smooth } & \\
\hline & $\mathrm{N}$ & $\%$ & $\mathrm{~N}$ & $\%$ & \\
\hline Massage & 14 & 63,6 & 8 & 36,4 & 0214 \\
\hline Not Massaged & 6 & 27,3 & 16 & 72,7 & 0,214 \\
\hline
\end{tabular}

From the two tables above, it can be seen that breastfeeding mothers who performed Lactation massage were 2.7 times more fluent with an OR: 2.773 compared to post partum mothers who performed a back massage and endorphin combination that was 0.2 times more fluent with an OR value: 0.214 (Jahriani. 2019). So it can be concluded that in accordance with the title that the writer researched, lactation massage is proven to be more smooth for breast milk production.

Increased oxytocin as much as $17 \%$ in mothers who received massage intervention in the back in post partum mothers. Oxytocin can increase milk production which is a trigger / let down reflex and as a prolactin releasing hormone. High levels of oxytocin in the mother causes fat metabolism in the body of the mother to increase until it causes lipolysis and causes an increase in blood glucose levels including breast milk. This causes a significant increase in body weight in infants. This is relevant to the eighth study, in this study there was an increase in body weight, an increase in the number of bowel movements and urination, as well as a longer sleep duration after breastfeeding in the intervention group (Ariani et al. 2017).

The administration of lavender aromatherapy can also trigger the release of oxytocin by changing the Dopamine subtype D3 receptor homoostasis which is a D2-like dopamine receptor, so that dopamine cannot eliminate lactotrophic cell function and its proliferation. Although it did not show any significant differences between groups based on the increase in BW / day measured, it can be seen that there was an increase in infant body weight in the control and treatment groups of 1.2 , or 3 . The highest average BB / day increase in the combination group (63,2 grams / day) and the lowest average weight increase / day in the control group (24.78 grams / day). From the Kruskal Wallis test, a significant value is greater than $\alpha(0.186>0.05)$. this can be interpreted as primigravida first stage maternal relactation supplementary by giving lavender aromatherapy, oxytocin massage, and combination methods do not significantly affect the baby's weight gain (Ariani et al. 2017).

The acupressure points for lactation technique is a solution to overcome the smooth production of breast milk. Acupressure points for lactation done through the meridian points in accordance with the organ to be addressed can help reduce discomfort. This is supported by the gate control theory, which in the theory explains that stimulation at an acupoint point on the 
meridian pathway will be passed on by large diameter A-Beta nerve fibers to the spinal nerves. From the statistical test results there are differences in 3 groups, which found that there were significant differences between the control group and the acupressure points for lactation group, with a value of $\mathrm{p}=0.004$ ( $\mathrm{p}<0.005)$. The insignificant results were in the control group and the oxytocin massage group, which was $\mathrm{p}=0.349(\mathrm{p}>0.005)$. And a significant difference between the acupressure points for lactation group and the oxytocin massage group with a value of $p=0.037$ ( $p$ $<0.05$ ) (Rahayu et al 2015). Mothers who received Acupressure Point For Lactation felt more comfort and more milk production than mothers who received oxytocin massage intervention, and mothers who received oxytocin massage intervention for ASI more than the control group. But after acupressure, many clients complained of skin rashes, redness, bruising and itching due to infections due to needle pricking. While acupresure is prohibited on clients who experience bleeding disorders and on clients who use blood-thinning drugs.

To expedite the process of breastfeeding, the breasts must be treated properly and appropriately to avoid interference and disease. Breast care is an important process during pregnancy and breastfeeding. In addition to making beautiful breasts come back, proper and regular breast care will make it easier for babies to breastfeed, stimulate milk production, and prevent breast injuries during the breastfeeding process. There is a significant effectiveness between breast care with a $\mathrm{P}$ value $<\alpha$ $(0,0001<0.05)$ and oxytocin massage with a $p$ value of 0,000 to the smooth flow of milk. This means that oxytocin massage is more effective against smooth milk expenditure compared to breast care. (Riordan \& Wambach. 2015). And back in previous research, that lactation massage is more effective in accelerating the expenditure of milk production compared to oxytocin massage (Dewi \& Aprilianti. 2018).

Table 5.Difference between effectiveness of oxytocin massage and clary sage aromatherapy with oxytocin massage on lactation onset (Septiani et al. 2018).

\begin{tabular}{lllllc}
\hline \multicolumn{1}{c}{ Intervensi } & n & Mean & SD & SE & p-value \\
\hline Oxytocin massage and aromatherapy Clary Sage & 19 & 4,21 & 0,855 & 0,196 & \multirow{2}{*}{0,000} \\
Oxytocin massage & 19 & 6,37 & 1,212 & 0,287 & \\
\hline
\end{tabular}

From the results of the analysis test above, oxytocin massage intervention and Clary Sage aromatherapy obtained an average lactation onset was 4.21 hours while in the oxytocin massage group was 6.37 hours (Septiani et al. 2018). But Clary Sage oil is not recommended for use in mothers who have a history of clary sage oil allergy and mothers who have low blood pressure because according to research in the department of basic nursing in Korea can reduce blood pressure in women with urinary incontinence or involuntary urination. From this study, it was shown that the group given clary sage oil intervention experienced a decrease in blood pressure which was significant in systolic. Avoid using clary sage oil in the eyes, nose and mouth.

\section{CONCLUSION}

Based on the analysis conducted by the author on several journals that are relevant to the author's research, it can be concluded that the respondent's milk production after lactation massage occurs when there is a significant increase marked by an increase in milk production. In addition to increasing milk production, lactation massage in post partum mothers can also reduce anxiety and prevent postpartum depression.

Lactation massage in post partum mothers is an easy and safe intervention. This intervention can also be carried out by the patient's husband or family after being trained by a midwife / health worker. In addition to being done by post partum mothers, lactation massage can also be done on foster mothers / adoptive mothers who want to breastfeed their babies. The advice that the author can give to health workers and the public is that lactation massage in post partum mothers can be used as an alternative relaxation method to increase and facilitate milk production.

\section{ACKNOWLEDGMENTS}


The author is thankful for respondents for their valuable information and its awareness to participate in this research

\section{CONFLICTS OF INTEREST}

The author declares that they have no conflict of interest

\section{REFERENCES}

Aini, Yuni N., Hadi, Sri R., Noor P., Donny K.M. (2017). Effect of Combination of Oxytocin Masaage and Hypnobreastfeeding on Uterine Involution and Prolactin Levels in Postpartum Mothers. Beliting Noursing Journal. 3(3)

Albertina, M., Melly., Rahmawati S. (2015). Hubungan Pijat Oksitosin dengan kelancaran produksi ASI pada Ibu Post partum section caesaria harike 2-3. Jurnal Husada Mahakam, 3(9): 452-521. Aprilianti, Cia, (2018). Pijat Laktasi dan Pijat Oksitosin terhadap Onset Laktasi di Kota Plangka Raya. Jurnal Ilmiah Bidan.6(1)

Ariani, D., Nur Aini Retno Hastuti, Agnestia Naning Dian Lovita \& Ni Luh Putu Herli Hastuti, (2017). Pengaruh Relaksasi Suplementer Dikombinasikan dengan pijat oksitosin dan aromaterapi Lavender terhadap Peningkatan Berat Badan Bayi di Malang Raya. Journal of Issuees in Midwifery. 1: 76-81.

Barirah, Eti M., Norma Y. (2017). The Effect of Combined Marmet and Oxytocin Massage to Colostrum Production Among Section Caesarean Mother. $2^{\text {nd }}$ Internasional Conference on Applied and Health. 3(6).

Bolman, M. (2015). Therapeutic Breast Massage in Lactation for The Management of Engorgement, Plugged Ducts, and Mastitis. Journal of Human Lactation: 1-9,

Darmasari, Sagita, Eryani P., Indah R. (2019). Effectiveness of The Combination of Marmet Technique and Oxytocin Massage Against The Breast Milk Production of Mother Postpartum.

Jurnal Kedokteran dan Kesehatan Publikasi Ilmiah Fakultas Kedokteran Universitas Sriwijaya. 6(3)

Department of Health R.I., (2015). Profil Kesehatan Indonesia. Jakarta

Delima, M., Gina Z.A., Ernalinda R. (2016). Pengaruh pijat oksitosin terhadap peningkatan produksi asi ibu menyusui di puskesmas plus mandiangin. Journal Ipteks Terapan: 2460-5611

Dewi, A.P.S., Eni I., Rina K. (2017). Kombinasi Pijat Oksitosin dan Endorphin terhadap Produksi ASI pada Ibu Postpartum. Jurnal Ilmiah Kesehatan Keperawatan, 13(2)

Dewi, R.A., Cia Aprilianti. (2018). Pijat Pada Ibu Postpartum dengan Onset Laktasi.1-4. Florida, g,

Hajerah, M.R. (2015). Hubungan Status Gizi dengan Onset Laktasi pada Ibu Postpartum di RS PKU Muhammadiyah Yogyakarta. Retrieved from: http://digilib.unisayogya.ac.id/511/1

Hapitria, Pepi. (2017). Pijat Laktasi. Pelatihan Metodik Khusus Clinical Instruktur Poltekkes Kemenkes Palangka Raya pada tanggal 29 April 2017.

Irawati, A. (2018). Pengaruh Endorphin Massage terhadap Rasa Nyaman selama Proses Persalinan di Puskesmas Mahalona Kabupaten LuwuTimur.

Jahriani, N. (2019). Excellent Midwifery Journal. Pengaruh Pijat Laktasi Terhadap Produksi ASI Pada Ibu Menyusui Di Kelurahan Sendang Sari Kabupaten Asahan, Excellent Midwifery Journal 2(2): 1-20

Ministry of Health RI. (2017). Riset Kesehatan Dasar: RISKESDAS. Jakarta: Balitbang Kemenkes RI

Machmudah, (2017). Peningkatan colostrum pada ibu postpartum Sectio Caesarea yang dilakukan pijat payudara dengan metode oketani. Rerieved from: http://uppu.unimus.ac.id/index.php/psn$12012010 /$ article/view/1203

Nugraheni, D. \&Heryati, K. (2016).Health Journal.Speos Method (Endorphin, Oxytocin and Suggestive Massage Stimulation) Can Increase Breast ASI and Increase Baby's Weight,Health Journal Vol. VIII. No. 1 April 2017.1-2 
Patimah, Siti, Imam DjamaluddinMashoedi\&SuharyoHadisaputro, (2019)The Effect of Lactapuncture Massage on Breast Milk Production through Prolactin Hormone Levels Changesin Dr. M. Ashari Hospital, Pemalang, Central Java, Indonesian Journal of Medicine. Volume 4.Nomer 1.Tahun 2019

Rahayu, D., Budi Santoso\&EstiYunitasari, (2015).Produksi ASI ibudenganintervensiAcupresure Point For LactationdanPijatOksitosin. JurnalNers, Volume 10 no.1, pp.9-19.

Riordan, J., \& Wambach, K. (2015). Breasfeeding and Human lactation ( ${ }^{\text {th }}$ ed ed.).

Safitri, W.N., Susulaningsih, Ardi P. (2015). Pijat Punggung dan Percepatan Pengeluaran ASI pada Ibu Post Partum. Jurnal Informasi Kesehatan Indonesia (JIKI), 1(2)

Septiani, R., Martini \& LiaFitri Andini, (2018).Efektivitas Pijat Oksitosin dan Aromaterapi Clary Sage terhadap Onset Laktasi. Jurnal Ilmiah Keperawatan Sai Betik. 14(2)

Seribu, H.J.D. \& Wasis P, (2015). Pijat Oksitosin dan Perawatan Payudara terhadap Kelancaran Pengeluaran ASI padaI bu Nifas. Medisains.13(1)

Suryani, I. (2015). Manfaat Massage tengkukdan massage otot Pectoralis Mayor terhadapPengeluaran ASI pada Ibu postpartum Hari ke 1 dan Hari ke 2. 1-5

Patel, Umesh, Gedam, D.D (2016). Effect of Massage on Lactation Among Postnatal Mothers. International Journal of Medical Research and Review, 1(1). 